\title{
Using Electrical Resistivity Tomography (ERT) to Delineate Subsurface Structures at Siloam Hot Spring in the Soutpansberg Basin, South Africa
}

\author{
Peter K. Nyabeze ${ }^{1}$, Oswald Gwavava ${ }^{1} \&$ Matome Sekiba $^{2}$ \\ ${ }^{1}$ Department of Geology, University of Fort Hare, Alice, South Africa \\ ${ }^{2}$ Geophysics Unit, Council for Geoscience, Pretoria, South Africa \\ Correspondence: Peter Nyabeze, Department of Geology, University of Fort Hare, Alice, EC., 5700, South Africa. \\ E-mail: 201013945@ufh.ac.za
}

Received: August 3, 2018

doi:10.5539/jgg.v10n4p19
Accepted: September 10, 2018

Online Published: November 16, 2018

URL: http://dx.doi.org/10.5539/jgg.v10n4p19

\begin{abstract}
Electrical resistivity tomography (ERT) was used to delineate subsurface structures at Siloam hot spring in the Soutpansberg Basin of South Africa. The spring water was reported to be hottest in South Africa. Groundwater with temperature ranging between $63.3^{\circ} \mathrm{C}$ and $67.5^{\circ} \mathrm{C}$ was observed flowing from the spring. Relatively wet areas were noted to the south and north of the spring. Electrical resistivity arrays with Dipole-dipole and WennerSchlumberger configurations were used. Current injection and potential dipole separations of $5 \mathrm{~m}$ and $10 \mathrm{~m}$ were applied across the spring. Inversion results for arrays with the shorter dipole separation of $5 \mathrm{~m}$ had better resolution. Resistivity sections were generated from inversion of ERT data. The resistivity values for the low and high resistive zones were $\rho \mathrm{a}<10$ and $\rho \mathrm{a}>70 \Omega \mathrm{m}$ respectively. Sub-horizontal resistivity zones were obtained from the inversion of Wenner-Schlumberger array survey data. High resistivity zones associated with dykes or sills were delineated on Dipole-dipole derived depth sections. Near vertical structures associated with water bearing faults or fractures were delineated at the Siloam hot spring.
\end{abstract}

Keywords: groundwater, hot spring, resistivity, inversion

\section{Introduction}

The focus of the study was to identify subsurface and water bearing structures at the Siloam hot spring in the Soutpansberg Basin in the Limpopo Province of South Africa. Hot water was observed flowing from the spring. Olivier et al. (2008) reported on the existence of hot springs in the Soutpansberg Basin. The temperature of water at the spring was reported to be in the range 63.3 to $67.5^{\circ} \mathrm{C}$ (Nyabeze et al., 2010; Shabalala et al. 2015), making it the hottest natural spring in South Africa. Nefuri (2013) highlighted an artesian borehole located $280 \mathrm{~m}$ southwest of the Siloam hot spring at longitude and latitude $30.1925^{\circ} \mathrm{E}$ and $22.895367^{\circ} \mathrm{S}$, respectively, that intersected water at $18 \mathrm{~m}$ and a dyke at $43 \mathrm{~m}$, and presented end of hole, volcanic rock drill chips. Holland and Witthüser (2011) in their analysis of borehole productivity in the Limpopo province reported that dykes, although less permeable dykes, acted as flow barriers and enhanced the accumulation of water with fissuring.

A resistivity survey utilising a Wenner array was used to map the Siloam fault near a hot spring in the Soutpansberg basin and highlighted a low resistivity zone associated with mud cones (Brandl et al., 2001). Nyabeze et al. (2010) reported on the occurrence of a low resistivity zone at the Siloam hot spring, from electrical conductivity surveys. Chirindja et al. 2016 applied the ERT to investigate the Urema flood plain in Mozambique and confirmed the existence of a semi-confined permeable aquifer confined by a 30 to $40 \mathrm{~m}$ clay layer. Chirindja et al. 2017 delineated fractured zones in Nampula, Mozambique concluded that the ERT method was better at resolving lateral variations in the bedrock. The resistivity method was used to study subsurface structures at Roosevelt hot springs in the USA (Ward et al., 1978 and Tripp et al., 1978). Befus et al. (2014) reported that the resistivity method has been used to map out the spatial heterogeneity and geological structure. Owen et al. (2006) and Wilkinson et al. (2010) and used the ERT method for measuring electrical resistivity of the subsurface. Al-Fares (2016) carried out inversion of resistivity data to delineate the 2D realistic vision of the local subsurface structures within the Yarmouk Basin, Syria. Sirieix et al. (2014) delineated near vertical low resistivity features due to clay and a confined low resistivity zone with values below $562 \Omega \mathrm{m}$ below the natural spring. 
The resistivity method is useful for the determination of subsurface weathered zone, thickness of sediments and differences in geology (MacDonald et al., 2008). Electrical geophysical methods can be used for rapid mapping of the subsurface soil using a non-destructive approach (Pozdnyakova et al., 2001). Resistivity surveys are useful for estimating depth of bedrock structures because different lithological units have differing resistivity values (Army, 1998). Orlando (2013) stated that Dipole-dipole arrays gave better resolution for subsurface areas with lower resistivity values compared to Schlumberger and Wenner arrays. Loke (2008) further mentioned that the Wenner array had the highest signal-to-noise ratio and is more reliable, among the conventional arrays. Tabbagh et al. (2007) described inversion as the application of an algorithm to determine unknown quantities that correspond to geometrical parameters. The inversion of the apparent resistivity to achieve the actual resistivity is based on the Occam inversion technique (Kaminsky et al., 2012). Constable et al. (1987) stated that the goal of inversion was to obtain the smoothest model from fitting data to a prescribed tolerance. Sirieix et al. (2014) obtained root mean square (RMS) fit errors between 5.9\% and 39.3\% with the high value from inversion of a section that had predominantly highly resistive limestone. Reynolds (2011) stated that the 2-D resistivity depth sections from 1-D inversion were based on the amalgamation of spatially averaged smoothness constrained 1-D inversions at each station. The modelling in 2-D is achieved using a finite element forward modelling approach that involves that comparison of the observed, original data and calculated model and measuring the degree of misfit in terms of the percentage Root Mean Square (RMS) error (Reynolds, 2011).

\section{Method}

Electrical resistivity surveys were carried out along a South to North (S-N) oriented profile across the spring (Figure 1). The survey profile elevation from South to North was between $830 \mathrm{~m}$ and $845 \mathrm{~m}$ above sea level. The topography value for each station was determined from GPS track files and appended to the field resistivity data. The hot water at the Siloam hot spring issues out of a borehole that was drilled into the Siloam hot spring. The ERT surveys were carried out in the months of May 2011 and May 2013, to investigate subsurface structures and water bearing zones. Two artesian boreholes Bh1 and Bh2, with warm water were observed $120 \mathrm{~m}$ and $190 \mathrm{~m}$ southeast of the hot spring respectively. 


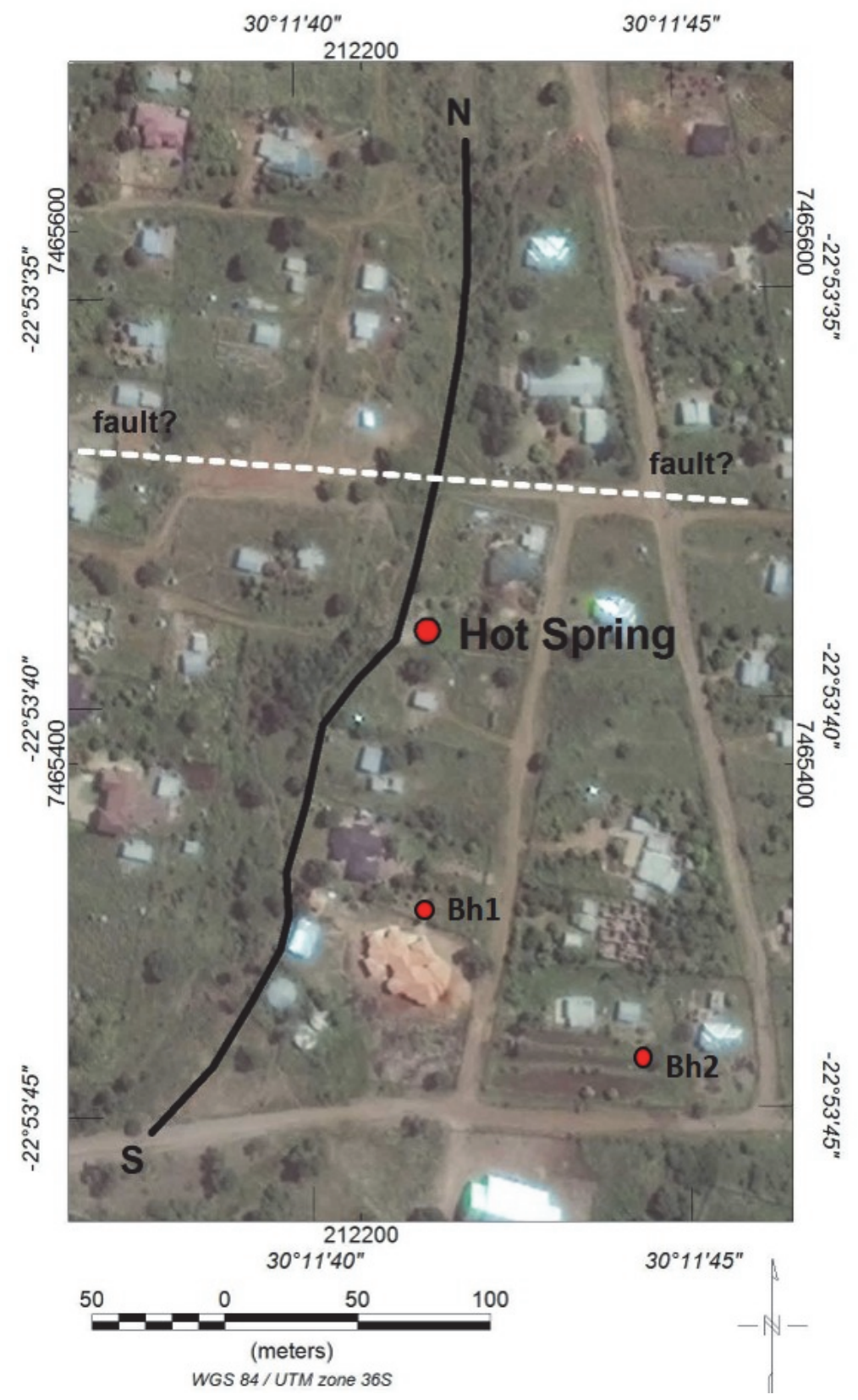

Figure 1. Location of the ERT profile-oriented south (S) to north (N), surveyed in May 2011 and May 2013, showing the location of the Siloam hot spring, Siloam Fault, and artesian boreholes Bh1 and Bh2.

The electrical resistivity tomography (ERT) method was used to record ground resistivity data. Dipole-dipole (DD) as well as combined Wenner-Schlumberger (WS) arrays were utilised, applying $5 \mathrm{~m}$ and $10 \mathrm{~m}$ dipole separations. The field deployment of the ERT method involved laying down an array of electrodes that were connected to the resistivity meter via a multi-core cable, the data acquisition process is automatic, and software controlled, with the ability to select the required array configuration. Resistivity data was recorded using an Iris Syscal Pro-72 multi electrode resistivity system. Multicore cables with lengths of $90 \mathrm{~m}, 180 \mathrm{~m}$, and $360 \mathrm{~m}$ were used. Stainless steel electrodes, $0.25 \mathrm{~m}$ long, were used for injecting current into the ground and for measuring voltages across electrodes. The temperature and precipitation data were collected and analysed for understanding the conditions of the ground during the ERT surveys. The survey dates, profile directions, profile lengths, and daily maximum temperatures, after Makungo 2016 are illustrated in Table 1.

The raw ERT dataset should be reviewed for data spikes, missing data, poor electrode contact resistances before 
carrying out the inversion. The profile topography was considered in the generation of the inversion models. The 1-D results were used to generate 2-D resistivity tomography sections whereas the other models presented in this paper were generated from the 2-D inversion of resistivity data. The inversion was carried out using ZondRes2D software (Zond, 2012). The inversion process was repeated automatically until the RMS error fell below the acceptable target convergence, limit $10 \%$. The inversion process results in the conversion of raw data resistivity pseudo-sections with pseudo-depths with modelled to true-resistivity depth sections.

The apparent resistivity $\rho_{a}$ is calculated from the current $(I)$ and voltage $(V)$ values, using Equation 1:

$$
\rho_{a}=K(V / I)
$$

In the Wenner array the separation of the potential and current electrodes is equal to separation $a$ and the apparent resistivity, $\rho_{a}$ is given by Equation 2 (Reynolds, 2011):

$$
\rho_{a}=2 \pi a(V / I)
$$

In the Dipole-dipole array, the distance between the current electrode and the potential electrode, $n a$ (the dipole separation factor) is usually an integer multiple, $n$, of the distance between the current or potential electrode pair; The value of, n, should not exceed six (6) to avoid the recording of noisy data (Loke, 2008). The apparent resistivity,

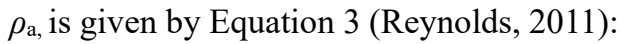

$$
\rho_{a}=\pi n(n+1)(n+2) a(V / I)
$$

The Schlumberger array is suitable for depth sounding. In the Schlumberger array the separation of potential electrodes is extremely smaller compared to the distance between the current injecting electrodes. The WennerSchlumberger array is a combination of the Wenner and Schlumberger. The $n$ factor for the Wenner-Schlumberger array is greater than 2 and the apparent resistivity, value for the array is given by Equation 4 (Reynolds, 2011):

$$
\rho_{a}=\pi n(n+1) a(V / I)
$$

The temperature and precipitation data were collected and analysed for understanding the conditions of the ground during the ERT surveys. The survey dates, profile directions, profile lengths, and daily maximum temperatures (Makungo 2016), and rainfall data (SAWS, 2016) are illustrated in Table 1.

Table 1. Profile parameters, day temperatures and precipitation data for the ERT surveys

\begin{tabular}{lllllll}
\hline $\begin{array}{l}\text { Date } \\
\text { (dd-m-yy) }\end{array}$ & $\begin{array}{l}\text { Dipole } \\
\text { (metres) }\end{array}$ & $\begin{array}{l}\text { Stations } \\
\text { (metres) }\end{array}$ & $\begin{array}{l}\text { Time } \\
\text { (hh:mm) }\end{array}$ & $\begin{array}{l}\text { Temperature Local } \\
\left({ }^{\circ} \mathrm{C}\right)\end{array}$ & $\begin{array}{l}\text { Temperature } \\
\text { Regional }\left({ }^{\circ} \mathrm{C}\right)\end{array}$ & $\begin{array}{l}\text { Precipitation } \\
\text { (mm) }\end{array}$ \\
\hline 08-May-11 & 10 & 0 to 400 & $\begin{array}{l}11: 26 \\
\text { to }\end{array}$ & N/A & 26.8 & 0 to 1.5 \\
\hline $04-$ May-13 & 5 & 0 to 265 & $\begin{array}{l}12: 53 \\
13: 07\end{array}$ & to 26.2 to 27.1 & 29.0 & 0 \\
\hline $08-$ May-13 & 5 & 80 to 435 & $\begin{array}{l}15: 23 \\
16: 43\end{array}$ & to 22.5 to 23.1 & 24.8 & 0 \\
\hline
\end{tabular}

Borehole locations, drilling depth and static water levels for the Siloam area were compiled (DWS, 2017). The average depth of the boreholes and static water was $63.56 \pm 33.42 \mathrm{~m}$ and $2.44 \pm 2.72 \mathrm{~m}$, respectively (Table 2).

Table 2. Borehole locations, drilling depth and static water levels for the Siloam area

\begin{tabular}{lllll}
\hline Borehole & Longitude & Latitude & Bh Depth $(\mathrm{m})$ & Water Level $(\mathrm{mbgl})$ \\
\hline Bh51 & 30.19148 & -22.90251 & 55.10 & 6.97 \\
\hline Bh52 & 30.18981 & -22.90028 & 63.00 & 6.37 \\
\hline Bh53 & 30.18842 & -22.90584 & 115.00 & 3.60 \\
\hline Bh138 & 30.19453 & -22.89890 & 93.50 & 0.12 \\
\hline Bh168 & 30.18759 & -22.90417 & 82.68 & 2.08 \\
\hline Bh440 & 30.19482 & -22.89905 & 65.75 & 0.34 \\
\hline Bh441 & 30.19299 & -22.89672 & 33.42 & 0.03 \\
\hline Hs229 & 30.17875 & -22.90595 & 0.00 & 0.00 \\
\hline Average & & & 63.56 & 2.44 \\
\hline Std.dev & & & 33.42 & 2.72 \\
\hline
\end{tabular}




\section{Results}

\subsection{Field Observations}

Weathered volcanic rock blocks roughly 30 to $90 \mathrm{~cm}$ wide were observed along the profile. These could be indications of weathered volcanic sill or dyke material. Weathered sedimentary rock and fractured quartz was observed in a gully adjacent the Siloam hot spring. Hot water was continuously issuing from a standpipe at the Siloam hot spring and community members were observed collecting water in 10,20 and 25 litre plastic containers. Two artesian boreholes Bh1 and Bh2 issuing warm water with temperatures above $40^{\circ} \mathrm{C}$ where identified in the survey area.

\subsection{Dipole-Dipole Arrays with $10 \mathrm{~m}$}

The May 2011 resistivity survey was a $10 \mathrm{~m}$, Dipole-dipole array with a length of $400 \mathrm{~m}$, with the spring located at station $240 \mathrm{~m}$ (Figure 2). The observed and pseudo sections indicated a lower resistivity top layer between stations $200 \mathrm{~m}$ and $400 \mathrm{~m}$. The 2-D inversion defined a horizontally layered model with a low resistivity zone with values of approximately $\rho a<13 \Omega \mathrm{m}$ and a thickness of $25 \mathrm{~m}$ to $50 \mathrm{~m}$. The hot spring at station $240 \mathrm{~m}$ occurs where the low resistivity zone has a thickness of approximately $25 \mathrm{~m}$. The model shows that the low resistivity zone has a thickness of about $50 \mathrm{~m}$ at station $200 \mathrm{~m}$. Near vertical zones with resistivity values $\rho a>70 \Omega \mathrm{m}$, as well as low resistivity, $\rho \mathrm{a}<13 \Omega \mathrm{m}$ sub-horizontal confined zones were delineated on the inversion model.

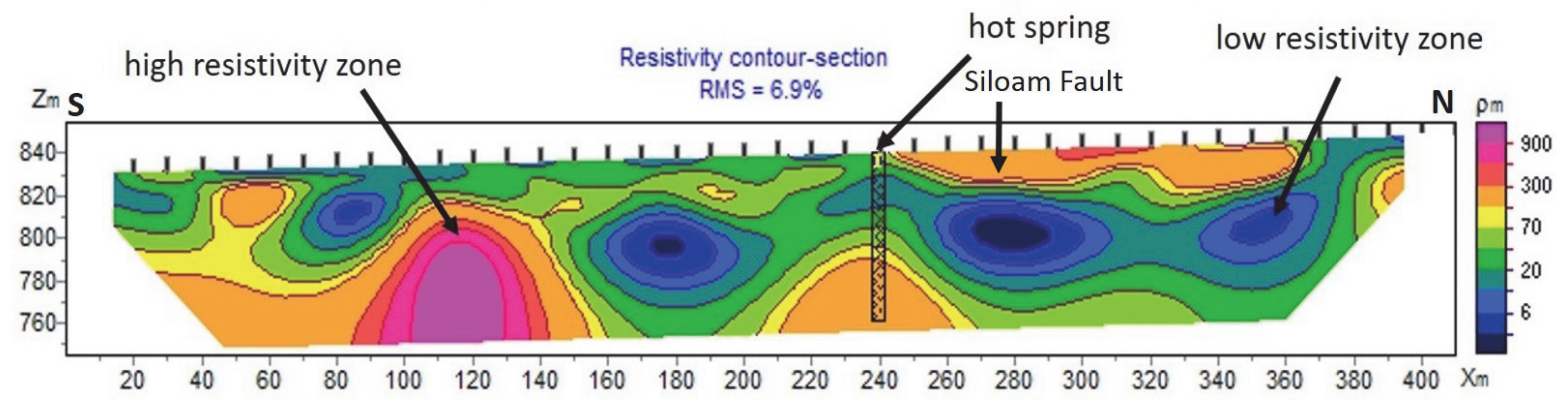

Figure 2. ERT 10 m, Dipole-Dipole array results for a May 2011 survey showing the 2-D modelled resistivity contour section with modelled resistivity $\rho m$ and elevation $\mathrm{Zm}$; The location of the hot spring as well as low and high resistivity zones are annotated on the modelled section

The data for May 2011 was subjected to 1-D inversion. 2-D resistivity sections were compiled from the 1-D inversion results. The resultant model showed that the borehole at the hot spring was drilled through zone at a depth of about $25 \mathrm{~m}$ with resistivity values $\rho a>13 \Omega \mathrm{m}$ and sub-horizontal zones with resistivity values $\rho \mathrm{a}<10$ $\Omega \mathrm{m}$ were delineated at depths below $25 \mathrm{~m}$ (Figure 3).

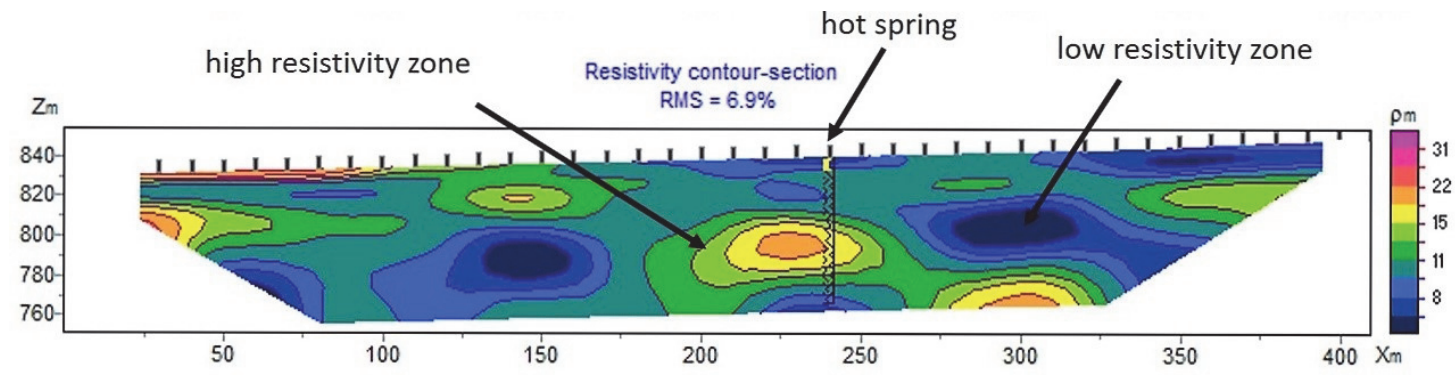

Figure 3. ERT $10 \mathrm{~m}$, Dipole-dipole array results for a May 2011 survey showing the 1-D modelled resistivity contour section with modelled resistivity $\rho m$ and elevation $\mathrm{Zm}$; The location of the hot spring, as well as subhorizontal low and high resistivity zones are annotated on the modelled section; The near surface low resistivity zones with $\rho a<10 \Omega \mathrm{m}$ occur below the spring as well as to the south and north of the spring

The RMS fit that was obtained for both the 1-D and 2-D inversion was $6.9 \%$ after 10 iterations, indicating that the models were a good representation of the real subsurface structure. The high resistivity zones delineated on the 1-D and 2-D models had resistivity values $\rho \mathrm{a}>13 \Omega \mathrm{m}$ and $\rho \mathrm{a}>70 \Omega \mathrm{m}$. The low resistivity values for the 1-D and 2-D models had values $\rho \mathrm{a}<10 \Omega \mathrm{m}$ and $\rho \mathrm{a}<13 \Omega \mathrm{m}$. The difference in the base resistivity values for the 1-D and 
2-D models could be attributed to the equivalence problem that is inherent in the inversion of resistivity data. The resistivity models that were generated from 1-D and 2-D inversion, highlighted the presence of lateral variations in subsurface, possible sub-horizontal, and sub-vertical structures. Both models showed a resistivity contrast at the position of the Siloam Fault at station $275 \mathrm{~m}$.

\subsection{Dipole-Dipole Arrays with $5 \mathrm{~m}$ dipoles}

The May 2013, $5 \mathrm{~m}$ Dipole-Dipole array survey produced results that showed lateral variation in resistivity along the profile (Figure 4). The May 2013 surveys were carried out on May $4^{\text {th }}$ for stations 0 to $265 \mathrm{~m}$ and May $8^{\text {th }}$ for stations $80 \mathrm{~m}$ to $435 \mathrm{~m}$. The 2-D inversion results showed the presence of a near vertical low resistivity zone between station $275 \mathrm{~m}$ and $300 \mathrm{~m}$ with values, $\rho a<30 \Omega \mathrm{m}$ at the position of the Siloam Fault and he model shows that borehole at the hot spring was drilled into a sub-horizontal zone relatively high resistivity values $\rho a>30 \Omega \mathrm{m}$ (Figure 4). The Siloam Fault was delineated on the inversion model.

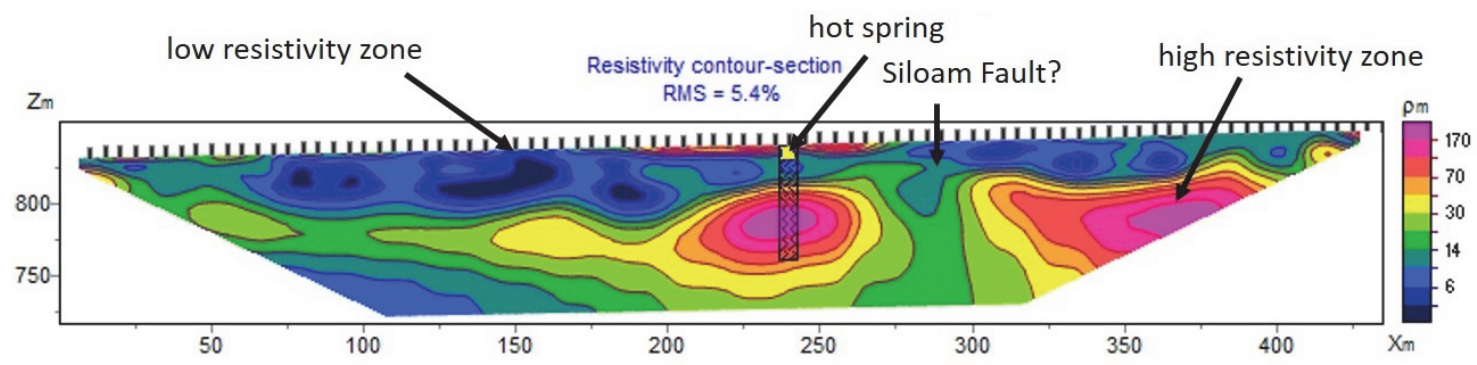

Figure 4. ERT $5 \mathrm{~m}$, Dipole-dipole array results for a May 2013 survey showing the 2-D modelled resistivity contour section with modelled resistivity $\rho m$ and elevation $\mathrm{Zm}$; The location of the hot spring, Siloam Fault as well as low and high resistivity zones are annotated on the modelled section

The data for May 2013, was filtered to reduce the misfit to 3.3\%, after carrying out 1-D inversion. The spring was drilled into a confined, low resistivity zone with, resistivity values, $\rho<13 \Omega \mathrm{m}$ (Figure 5). The model highlighted several near vertical zones with high resistivity values $\rho a>35 \Omega \mathrm{m}$ that could be fractures dykes.

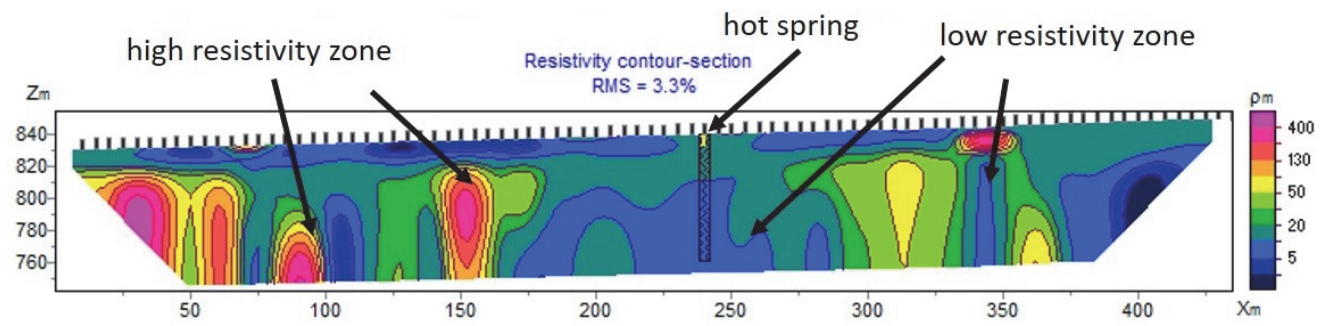

Figure 5. ERT $5 \mathrm{~m}$ Dipole-dipole array results for a May 2013 survey showing the 1-D modelled resistivity contour section with modelled resistivity $\rho m$ and elevation $\mathrm{Zm}$; The location of the hot spring, as well as near vertical low and high resistivity zones are annotated on the modelled section.

\subsection{Wenner-Schlumberger Arrays}

ERT results for a $400 \mathrm{~m}$, south to north oriented, $10 \mathrm{~m}$ dipole Wenner-Schlumberger array also recorded in May 2011 have low resistivity zones where, $\rho a<20 \Omega \mathrm{m}$ (Figure 6). The resistivity model indicated a low resistivity top layer with a thickness ranging between $20 \mathrm{~m}$ and $25 \mathrm{~m}$ that could be associated with a weathered water bearing zone. The resistivity zone was sub-horizontal and had values $\rho a>30 \Omega \mathrm{m}$. 


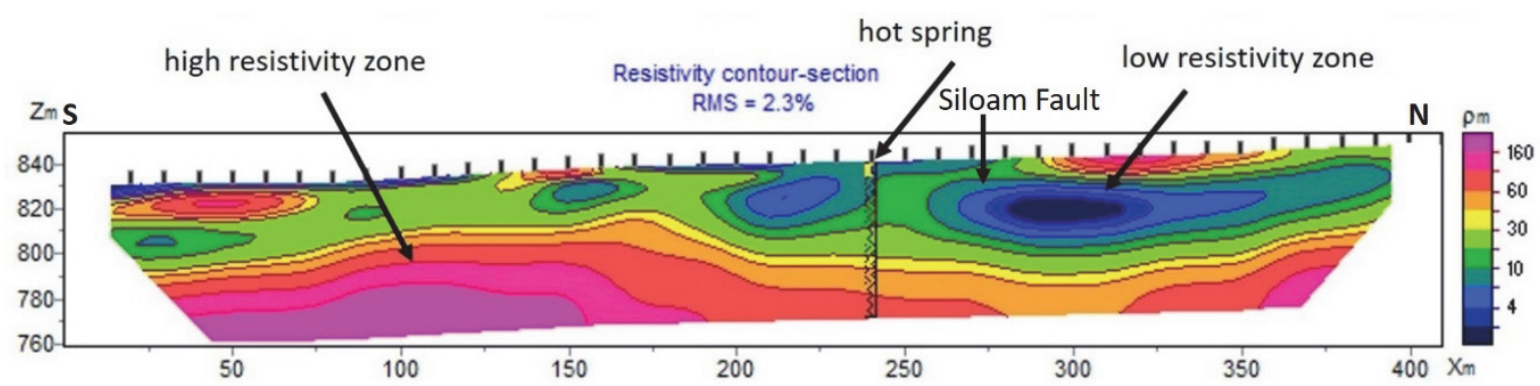

Figure 6. ERT $10 \mathrm{~m}$, Wenner-Schlumberger array results for the May 2011 survey showing the 2-D modelled resistivity contour section with modelled resistivity $\rho m$ and elevation $Z m$; The location of the hot spring, as well as sub-horizontal low and high resistivity zones are annotated on the modelled section

ERT results for a $435 \mathrm{~m}$ south to north oriented, $5 \mathrm{~m}$ Wenner-Schlumberger array recorded in May 2013 had low resistivity zones where $\rho a<20 \Omega \mathrm{m}$ (Figure 7). The low resistivity zone with $\rho \mathrm{a}<20 \Omega \mathrm{m}$ was approximately 20 $\mathrm{m}$ thick to the south of the hot spring between stations $75 \mathrm{~m}$ and $225 \mathrm{~m}$.

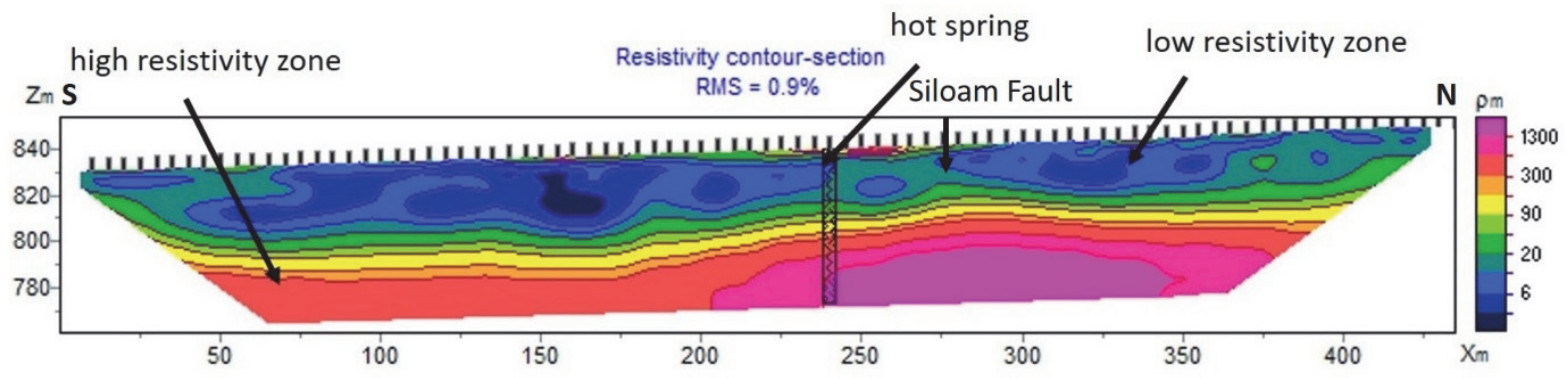

Figure 7. ERT $5 \mathrm{~m}$, Wenner-Schlumberger array results for a May 2013 survey showing the 2-D modelled resistivity contour section with modelled resistivity $\rho m$ and elevation $\mathrm{Zm}$; The location of the hot spring, as well as sub-horizontal low and high resistivity zones are annotated on the modelled section

The Wenner-Schlumberger, 2-D inversions models for May 2011 and May 2013 surveys highlighted horizontal variations in resistivity. The subtle differences in the May 2011 and May 2013 could be attributed to factors such as the equivalence problem that is inherent in the inversion of resistivity data. The results showed that the $1.5 \mathrm{~mm}$ precipitation recorded in May 2011 and the difference in daily temperatures during the survey days did not have a noticeable effect on the resultant resistivity models.

\section{Discussion}

Relatively similar structures were resolved by both May 2011 and May 2013 resistivity models. The Dipole-dipole array resistivity, 2-D models resolved lateral variations better in the subsurface compared to Wenner-Schlumberger array. The sections generated from 1-D inversion results highlighted the presence of near vertical high resistivity zones. The 2-D inversion results for Dipole-Dipole array surveys, delineated broader horizontal variations in the subsurface. Results for Wenner-Schlumberger array surveys mapped sub-horizontal layers that could be attributed to sills and water bearing sedimentary layers. Al-Fares (2016) in a similar study concluded that lateral variations were more defined better using a profiling technique as compared to single 1-D inversion techniques. Beard \& Morgan (1991) in their assessment of 2-D resistivity structures using 1-D inversion did not find any major differences between results of 1-D and 2-D inversions but observed that 2-D surface geometry could be delineated with certainty from 1-D inversion.

The resistivity was found to be increasing from surface from values below $10 \Omega \mathrm{m}$ for confined low resistivity zones to values above $100 \Omega \mathrm{m}$, for the high resistivity confining zones. According the Army (1998) resistivity values for sediments are in the range 20 to $200 \Omega \mathrm{m}$ with metamorphic and igneous rocks having high values above $50 \Omega \mathrm{m}$. Kayode et al. (2016) in their study on crystalline aquifers located in southwestern Nigeria, reported that resistivity values in the range 50 to $250 \Omega \mathrm{m}$ were associated with weathered material that formed the groundwater aquifer. 
The RMS fit for the $10 \mathrm{~m}$ Dipole-Dipole inversion models for both surveys were 5.4 and $6.9 \%$ respectively for 10 iterations. The RMS error was lower, with values below $5 \%$. for the Wenner-Schlumberger array and the $5 \mathrm{~m}$ Dipole-Dipole inversion models. Orlando (2013) obtained root mean square errors (RMS) ranging from $1.8 \%$ to $5.8 \%$ for resistivity data iterations in the range of 6 to 7 and these were deemed to be acceptable.

The depth of weathering inferred from the low resistivity zones ranged from $20 \mathrm{~m}$ to $40 \mathrm{~m}$. The occurrence of water bearing zones at depths of $10 \mathrm{~m}$ to $30 \mathrm{~m}$ was based on the observed outflowing spring water, wet zones to the south and north of the spring, and the low resistivity zones from the inversion models. DWAS (2017) confirmed the occurrence of shallow water depths and boreholes. Muchingami et al. 2013 attributed the reduction of subsurface resistivity to almost zero, to water content and solute content above $25 \%$. Shabalala et al. 2015 confirmed that the water at the springs in the Soutpansberg basin had a relatively high sodium content. Yeh et al. 2002 observed that the variability of the moisture content influenced the resistivity inversion modelling by contributing to higher levels of uncertainty in the interpretation of results. Differential weathering in areas with hot springs has been attributed to water infiltration in fault zones (Olivier et al., 2008). Bala \& Cichy (2015) however noted the contribution of infiltrating conductive mud to the equivalence problem that results in the uncertain determinations of layer resistivity and thickness values.

In the interpretation of delineated subsurface structures, the geology was assumed to be generally homogeneous. The near vertical structures that could be associated with faults or fractures and dykes or sills respectively were delineated near the Siloam hot spring. Befus et al. 2014 in their analysis of electrical resistivity anomalies concluded that the subsurface geology was heterogeneous. Bania \& Ćwiklik (2013) stated that single profile ERT models were ambiguous in that they did not only define structures under the survey line but were influenced by other adjacent objects in the subsurface.

\section{Conclusion}

Subsurface structures were delineated at the Siloam hot spring using results of the ERT technique that were obtained in May 2011 and May 2013. Moisture bearing zones characterised by low near surface resistivity values, were delineated the south and north of the hot spring. Near vertical structures were better resolved using the DipoleDipole array. Layered structures and horizontal variation in resistivity were defined better using the WennerSchlumberger array inversion results. Lateral and vertical discontinuities in the bedrock that could be due to faults, fractures, geological contacts, or drainage channels were delineated. The depth of the water bearing top layer was inferred to be between $20 \mathrm{~m}$ and $40 \mathrm{~m}$ based on the lower resistivity zones on the Wenner-Schlumberger inversion models. The interpreted depth to the water bearing zone was comparable to the water strike depth of $20 \mathrm{~m}$ at the artesian boreholes that were drilled to the south of the hot spring. The research highlighted the uncertainties associated with the inversion and interpretation of ERT results. The delineated low resistivity zones are good targets for drilling boreholes for groundwater. The Siloam hot spring water, therefore exploits near vertical fractures or geological contact zones that were inferred from the ERT inversion models.

\section{Acknowledgments}

This research project was made possible through funding from Water Research Commission (WRC) K5/1959; National Research Foundation (NRF) Grant UID 82443; Mining Qualifications Authority (MQA), Council for Geoscience, South Africa Projects: ST-2009-1015, ST-2011-1120, \& ST-2013-1169. Geosoft Inc. is thanked for providing data analysis, processing, imaging and interpretation software. Zond Software is thanked for providing software for resistivity inversion.

\section{References}

Al-Fares, W. (2016). Using vertical electrical soundings for characterizing hydrogeological and tectonic settings in Deir El-Adas area, Yarmouk Basin, Syria. Acta Geophysica, 64(3), 610-632. https://doi.org/10.1515/acgeo2016-0025

Army, U. S. (1998). Geophysical exploration for engineering and environmental investigations. Technical engineering and design guides as adapted from the: US Army Corps of Engineers, 23, 204.

Bała, M., \& Cichy, A. (2015). Evaluating Electrical Anisotropy Parameters in Miocene Formations in the Cierpisz Deposit. Acta Geophysica, 63(5), 1296-1315. https://doi.org/10.2478/s11600-014-0252-3

Bania, G., \& Ćwiklik, M. (2013). 2D electrical resistivity tomography interpretation ambiguity - example of field studies supported with analogue and numerical modelling. J Geol, Geoph Env 39(4), 331-339. https://doi.org/10.7494/geol.2013.39.4.331

Barker, O. B., Brandl, G., Callaghan, C. C., Eriksson, P. G., \& van Der Neut, M. (2006). The Soutpansberg and 
Waterberg groups and the Blouberg formation. In MR Johnson, MR Anhaeusser and CR Thomas, The geology of South Africa, 301-318.

Beard, L. P., \& Morgan, F. D. (1991). Assessment of 2-D resistivity structures using 1-D inversion. Geophysics, 56(6), 874-883. https://doi.org/10.1190/1.1443106

Befus, K. M., Cardenas, M. B., Tait, D. R., \& Erler, D. V. (2014). Geoelectrical signals of geologic and hydrologic processes in a fringing reef lagoon setting. Journal of hydrology, 517, 508-520. https://doi.org/10.1016/j.jhydrol.2014.05.070

Brandl, G. (1981). The geology of the Messina area. Explanation of 1:250 000 sheet 2230, Geological Survey of South Africa. Council for Geoscience, Pretoria, South Africa.

Brandl, G., Mitchev, S. A., Stettler, E. H., Graham, G., \& Smit, J. P. (2001). Liquefaction-induced features along the Siloam Fault, Soutpansberg: seismic origin or ground water phenomenon? In: 7th SAGA Biennial Technical Meeting and Exhibition, October 2012.

Chirindja, F. J., Dahlin, T., \& Juizo, D. (2017). Improving the groundwater-well siting approach in consolidated rock in Nampula Province, Mozambique Hydrogeol J (2017) 25: 1423. https://doi.org/10.1007/s10040-0171540-1

Chirindja, F. J., Dahlin, T., Perttu, N., Steinbruch, F., \& Owen, R. (2016). Combined electrical resistivity tomography and magnetic resonance sounding investigation of the surface-water/groundwater interaction in the Urema Graben, Mozambique. Hydrogeology journal, 24(6), 1583-1592. https://doi.org/10.1007/s10040016-1422-y

Constable, S. C., Parker, R. L., \& Constable, C. G. (1987). Occam's inversion: A practical algorithm for generating smooth models from electromagnetic sounding data. Geophysics, 52(3), 289-300. https://doi.org/10.1190/1.1442303

DWAS (2017). National Groundwater Archive. Department of Water and Sanitation, Republic of South Africa. Accessed September 30, 2017.

Fox, R. C., Hohmann, G. W., Killpack, T. J. \& Rijo, L. (1980). Topographic effects in resistivity and inducedpolarization surveys. Geophysics, 45(1), 75-93. https://doi.org/10.1190/1.1441041

Holland, M., \& Witthüser, K. T. (2011). Evaluation of geologic and geomorphologic influences on borehole productivity in crystalline bedrock aquifers of Limpopo Province, South Africa. Hydrogeology Journal, 19(5), 1065-1083. https://doi.org/10.1007/s10040-011-0730-5

Kaminsky, A. E., Luhmanov, V. L., \& Sakovskaya, A. V. (2012, September). Full Wave Form 2.5 D Inversion of Time Domain Induced Polarization. In Near Surface Geoscience 2012-18th European Meeting of Environmental and Engineering Geophysics. https://doi.org/10.3997/2214-4609.20143477

Kayode, J. S., Adelusi, A. O., Nawawi, M. N. M., Bawallah, M. \& Olowolafe, T.S. (2016). Geo-electrical investigation of near surface conductive structures suitable for groundwater accumulation in a resistive crystalline basement environment: A case study of Isuada, southwestern Nigeria. Journal of African Earth Sciences, 119, 289-302. https://doi.org/10.1016/j.jafrearsci.2016.04.009

Loke, M. H. (2008). RES2DINV version 3.54-Rapid 2D resistivity and IP inversion using the least-squares method: Geoelectrical Imaging 2-D and 3-D. Geotomo Software, Malaysia, 130p.

Loke, M. H., Wilkinson, P. B., Tejero-Andrade, A., \& Kruse, S. (2015). Optimized Arrays for Resistivity Measurements Confined to the Perimeter of a Survey Area. In Near Surface Geoscience 2015-21st European Meeting of Environmental and Engineering Geophysics, September 2015. https://doi.org/10.3997/22144609.201413793

Macdonald, A. M., Davies, J., \& Calow, R. C. (2008). African hydrogeology and rural water supply. Applied Groundwater Studies in Africa. IAH Selected Papers in Hydrogeology, 13, 127-148. https://doi.org/10.1016/j.desal.2008.05.100

Makungo, R. (2016). Weather station data for Siloam Police Station, Siloam, Un-Published, University of Venda, South Africa.

Muchingami, I., Nel, J., Xu, Y., Steyl, G., \& Reynolds, K. (2013). On the use of electrical resistivity methods in monitoring infiltration of salt fluxes in dry coal ash dumps in Mpumalanga, South Africa. Water SA, 39(4), 491-498. https://doi.org/10.4314/WSA.V39I4.7 
Nefuri (2013). Oral evidence: Borehole parameters of a drilled artesian borehole west of Siloam hot spring at the Nefuri residence, Check-line, oral communication, March 3, 2013, Unpublished.

Nyabeze, P. K., Venter, J. S., Olivier, J., \& Motlakeng, T. R. (2010). Characterization of the thermal aquifer associated with the Siloam hot spring in Limpopo, South Africa. In Totolo, O. (Ed). (2010). Water Resource Management - 2010, Calgary. https://doi.org/10.2316/P.2010.686-059

Olivier J., van Niekerk H. J., \& van der Walt I. J. (2008). Physical and chemical characteristics of thermal springs in the Waterberg area in Limpopo Province, South Africa. Water SA, 34(2), 2008, 166-171.

Orlando, L. (2013). Some considerations on electrical resistivity imaging for characterization of waterbed sediments. Journal of Applied Geophysics, 95, 77-89. https://doi.org/10.1016/j.jappgeo.2013.05

Owen, R. J., Gwavava, O., \& Gwaze, P. (2006). Multi-electrode resistivity survey for groundwater exploration in the Harare greenstone belt, Zimbabwe. Hydrogeology Journal, 14(1-2), 244-252. https://doi.org/10.1007/s10040-004-0420-7

Pozdnyakova, L., Pozdnyakov, A., \& Zhang, R. (2001). Application of geophysical methods to evaluate hydrology and soil properties in urban areas. Urban Water, 3(3), 205-216. https://doi.org/10.1016/S14620758(01)00042-5

Reynolds, J. M. (2011). An introduction to applied and environmental geophysics. John Wiley and Sons, $2^{\text {nd }}($ ed.), p.696.

SAWS (2016). South African Weather Service. Temperature and Rainfall data the Thohoyandou Weather Station, WO-07236646.

Shabalala A, Nyabeze PK, Mankayi Z, \& Olivier J. (2015) An analysis of the groundwater chemistry of hot springs in the Soutpansberg basin in South Africa: Recent data. SA J Geol 118:83-90. https://doi.org/10.2113/gssajg.118.1.87

Sirieix, C., Riss, J., Rey, F., Prétou, F., \& Lastennet, R. (2014). Electrical resistivity tomography to characterize a karstic Vauclusian spring: Fontaine d'Orbe (Pyrénées, France). Hydrogeology Journal, 22(4), 911-924. https://doi.org/10.1007/s10040-013-1095-8

Tabbagh, J., Samouëlian, A., Tabbagh, A., \& Cousin, I. (2007). Numerical modelling of direct current electrical resistivity for the characterisation of cracks in soils. Journal of Applied Geophysics, 62(4), 313-323. https://doi.org/10.1016/j.jappgeo.2007.01.004

Telford, W. M., Geldart, L. P., \& Sheriff, R. E. (1990). Applied geophysics (Vol. 1). Cambridge University Press, p.770.

Tripp, A. C., Ward, S. H., Sill, W. R., Swift Jr, C. M., \& Petrick, W. R. (1978). Electromagnetic and Schlumberger resistivity sounding in the Roosevelt Hot Springs KGRA. Geophysics, 43(7), 1450-1469. https://doi.org/10.1190/1.1440908

Ward, S. H., Parry, W. T., Nash, W. P., Sill, W. R., Cook, K. L., Smith, R. B., Chapman, D. S., Brown, F. H., Whelan, J. A., \& Bowman, J. R. (1978). A summary of the geology, geochemistry, and geophysics of the Roosevelt hot springs thermal area, Utah. Geophysics, 43(7), 1515-1542. https://doi.org/10.1190/1.1440912

Wilkinson, P. B., Meldrum, P. I., Kuras, O., Chambers, J. E., Holyoake, S. J., \& Ogilvy, R. D. (2010). Highresolution electrical resistivity tomography monitoring of a tracer test in a confined aquifer. Journal of Applied Geophysics, 70(4), 268-276. https://doi.org/10.1016/j.jappgeo.2009.08.001

Yeh, T. C. J., Liu, S., Glass, R. J., Baker, K., Brainard, J. R., Alumbaugh, D., \& LaBrecque, D. (2002). A geostatistically based inverse model for electrical resistivity surveys and its applications to vadose zone hydrology. Water Resources Research, 38(12). https://doi.org/10.1029/2001wr001204

Zond (2012). ZondRes2D program for two-dimensional interpretation of data obtained by resistivity and induced polarization methods (land, borehole and marine variants). Zond Geophysical Software, Saint-Petersburg, p.70.

\section{Copyrights}

Copyright for this article is retained by the author(s), with first publication rights granted to the journal.

This is an open-access article distributed under the terms and conditions of the Creative Commons Attribution license (http://creativecommons.org/licenses/by/4.0/). 